\title{
APLIKASI METODE FUZZY C-MEANS UNTUK MENENTUKAN TINGKAT PENGANGGURAN
}

\author{
Dorteus L. Rahakbauw ${ }^{1}$, Lexy J. Sinay ${ }^{2}$, Vilomina Enus ${ }^{3}$ \\ 1,2,3) Jurusan Matematika Fakultas MIPA Universitas Pattimura \\ Jln. Ir. M. Putuhena, Kampus Unpatti, Poka-Ambon \\ e-mail: ${ }^{1}$ lodewyik@gmail.com; ${ }^{2}$ lj.sinay@staff.unpatti.ac.id
}

\begin{abstract}
Abstrak
Pada penelitian ini Algoritma Fuzzy C-Means digunakan untuk menentukan tingkat pengangguran pada 11 kabupaten di Provinsi Maluku. Variabel yang digunakan dalam penelitian ini adalah Jumlah Penduduk, Tingkat Partisipasi Angkatan Kerja (TPAK), Jumlah Angkatan Kerja, Penduduk Usia 15 Tahun ke Atas, Tingkat Pengangguran Terbuka (TPT) dengan 11 kabupaten yaitu kabupaten Maluku Tenggara Barat (MTB), Maluku Tenggara (MTr), Maluku Tengah (MTh), Buru (B), Kepulauan Aru (KA), Seram Bagian Barat (SBB), Seram Bagian Timur (SBT), Maluku Barat Daya (MBD), Buru Selatan (BS), Ambon (A), Tual (T). Hasil penelitian yang diperoleh berdasarkan pengelompokan cluster dengan (Kota, Derajat Keanggotaan) adalah Cluster I : (MTB ; 0,9768), (MTr ; 0,8175), (B ; 0,9982), (SBB ; 0,7808), (SBT ; 0,8483), Cluster II : (KA ; 0,6426), (MBD ; 0,9946), (BS ; 0,9587), (T ; 0,9900) dan Cluster III : (MTh ; 0,9986), (A ; 0,9986). Cluster I merupakan kabupaten - kabupaten yang termasuk dalam pengangguran tingkat rendah, Cluster II merupakan kabupaten kabupaten yang termasuk dalam pengangguran tingkat sedang, dan cluster III kabupaten - kabupaten yang termasuk dalam pengangguran tingkat tinggi.
\end{abstract}

Kata Kunci: Pengklasteran , Fuzzy C - Means, Pengangguran.

\section{APPLICATION OF FUZZY METHOD C-MEANS CLUSTERING TO DETERMINE THE JOBLESSNESS RATE}

\begin{abstract}
In this research, the Algorithm of Fuzzy C-Means clustering is used to determine the level of Joblessness in 11 districts in Maluku Province. The variables used in this study is the number of population, the labor force participation rate (LFPR), the number of the labor force, the population aged 15 years and over, the rate of open Joblessness (TPT) with 11 districts, namely districts South East West Moluccas (MTB), South East Moluccas (MTr), Center Moluccas (MTh), Buru (B), Aru Islands (KA), West Seram (SBB), East Seram (SBT), Southwest Moluccas (MBD), Buru South (BS), Ambon (A), Tual (T). The results obtained based on the grouping of the cluster with (the City, the Degree of Membership) is the Cluster I : (MTB ; 0,9768), (MTr ; 0,8175), (B ; 0,9982), (SBB ; 0,7808), (SBT ; 0,8483), Cluster II : (KA ; 0,6426), (MBD ; 0,9946), (BS ; 0,9587), (T ; 0,9900) and Cluster III : (MTh ; 0,9986), (A ; 0,9986). Cluster I is the districts included in the joblessness rate is low, cluster II is one of the districts included in the joblessness rate was, and cluster III districts are included in the joblessness level high.
\end{abstract}

Keywords: Clustering , Fuzzy C-Means, Joblessness

\section{Pendahuluan}

Dalam ekonomi kapitalisme modern masalah utama dalam ekonomi nasional adalah adanya penggangguran. Pengangguran merupakan masalah yang sangat umum di hadapi oleh Negara berkembang dimana orang yang menganggur didefinisikan sebagai orang yang tidak bekerja, dan secara aktif mencari pekerjaan. Pengangguran adalah mereka yang berusia kerja yang sedang tidak bekerja dan tidak mencari pekerjaan Masalah ini muncul karena perekonomian tidak mencapai kondisi kesempatan kerja penuh sehinggaa dari sekelompok orang yang tidak dapat bekerja walaupun mereka sangat menginginkan pekerjaan tersebut. Kesempatan untuk bekerja tersebut hilang karena perusahaan, organisasi pemerintahan dan badan usaha lain sudah cukup mempekerjakan karyawannya untuk menghasilkan produk barang dan jasa . Hal ini 
mengakibatkan adanya sekelompok orang yang harus menerima kenyataan tidak dapat bekerja dalam system ekonomi tersebut.

Sebab umum yang mempengaruhi pengangguran adalah: Angkatan kerja yang terus meningkat dan pertumbuhan kesempatan kerja yang tidak seimbang. Angkatan kerja yang mencari kerja tidak memenuhi persyaratan yang diminta oleh dunia usaha. Tingkat investasi yang rendah. Sebab khusus yang mempengaruhi pengangguran adalah: Tidak adanya lowongan pekerjaan. Tidak memenuhi persyaratan yang telah di tetapkan. Tenaga kerja merupakan faktor yang sangat krusial bagi pembangunan ekonomi di setiap negara. Tujuan peningkatan penyerapan tenaga kerja sering menjadi prioritas dalam pembangunan suatu negara. Ketenagakerjaan Tenaga kerja merupakan penduduk yang berada dalam usia kerja. Penduduk tergolong tenaga kerja jika penduduk tersebut telah memasuki usia kerja. Batas usia kerja yang berlaku di Indonesia adalah berumur 15 tahun - 64 tahun. Tenaga kerja merupakan salah satu faktor produksi yang penting setiap negara.

\section{Tinjauan Pustaka}

Fuzzy C-Means cluster pertama kali dikemukakan oleh Dunn (1973) dan kemudian dikembangkan oleh Bezdek (1981) yang banyak digunakan dalam pattern recognition. Pengelompokkan data dengan metode ini sebelumnya sudah dibuat dan digunakan, namun dengan aplikasi yang berbeda bahkan menggunakan program yang dapat mempermudah. Beberapa yang pernah dibuat adalah : Muhammad Faisal Mirza (2013) Judul penelitian ini adalah Metode Clustering dengan Algoritma Fuzzy C-Means untuk Rekomendasi pemilihan bidang keahlian pada program studi teknik informatika. Dalam penelitian ini Algoritma Fuzzy C - Means untuk rekomendasi penjurusan dapat diterapkan dengan manfaat penentu mahasiswa masuk kelompok mana dan setiap kelompok di identifikasikan sebagai jurusan apa. Ubai Fadilah (2011) Judul penelitian ini adalah Analisis penyandang masalah kesejahteraan social di Indonesia menggunakan metode Fuzzy C-Means clustering dan biplot. Dalam penelitian ini Fuzzy C-Means pengclusteran digunakan untuk mengelompokkan data kedalam cluster tertentu sedangkan biplot untuk memberikan penerangan kedalam plot. Widiasari Sediyono (2006) Judul penelitian ini adalah Penentuan Lokasi Fasilitas Gudang menggunakan Fuzzy C - Means (FCM). Dalam penelitian ini perangkat lunak yang telah di buat dapat digunakan untuk menyelesaikan masalah ini dengan menggunakan metode Fuzzy CMeans adalah dengan menentukan pusat cluster pada lokasi fasilitas

\section{Hasil dan Pembahasan}

\subsection{Data Input}

Data yang digunakan dalam penelitian ini adalah data primer yang di ambil di kantor Badan Pusat Statistik (BPS) Provinsi Maluku dari tahun 2008-2015 . Dalam penelitian ini variabel yang digunakan untuk Menentukan tingkat pengangguran pada 11 kabupaten di provinsi Maluku menggunakan algoritma Fuzzy CMeans adalah sebagai berikut :

1. $x_{i 1}$ : Rata-rata Jumlah penduduk

2. $x_{i 2}$ : Rata-rata Tingkat Partisipasi Angkatan Kerja (TPAK)

3. $x_{i 3}$ : Rata-rata Jumlah Angkatan Kerja

4. $x_{i 4}$ : Rata-rata Penduduk usia 15 tahun ke atas

5. $x_{i 5}$ : Rata-rata Tingkat Pengangguran Terbuka (TPT)

\subsection{Hasil Pengclusteran}

Bab ini memuat tentang analisis data dan hasil pengklasteran menggunakan metode Fuzzy C-Means dengan menggunakan Microsoft Excel. Data yang digunakan dalam penelitian ini, diambil dari kantor BPS (Badan Pusat Statistik) Provinsi Maluku, datanya dapat dilihat pada lampiran 1. Untuk membagi 11 Kabupaten menjadi 3 kelompok, menggunakan beberapa variabel, yaitu:

1. Jumlah Penduduk

Jumlah penduduk adalah banyaknya orang yang mendiami suatu wilayah negara. Penduduk suatu negara dapat dibagi dalam dua kelompok, yakni kelompok penduduk usia kerja (tenaga kerja) dan kelompok penduduk bukan usia kerja.

2. Tingkat Partisipasi Angkatan Kerja (TPAK)

TPAK adalah penduduk yang berusia > 15 tahun yang berpartisipasi dalam kegiatan ekonomi 
3. Angkatan Kerja

Angkatan Kerja adalah peduduk yang bekerja atau tidak bekerja (pengangguran)

4. Penduduk Usia $>15$ tahun

Penduduk yang berusia $>15$ tahun adalah tenaga kerja yang merupakan angkatan kerja dan bukan angkatan kerja

5. Pengangguran Terbuka Pengangguran Terbuka adalah :

- Penduduk yang tidak punya pekerjaan dan mencari pekerjaan

- Penduduk yang tidak punya pekerjaan dan menyiap kan usaha

- Penduduk yang tidak punya pekerjaan dan tidak mencari pekerjaan

- Penduduk yang punya pekerjaan tetapi belum mulai bekerja

Langkah awal dari proses pengklasteran ini adalah menentukan parameter awal yang akan digunakan untuk menyelesaikan masalah dengan algoritma Fuzzy C- Means. Parameter-parameter tersebut adalah
a. Jumlah cluster (c)
$=3$
b. Pangkat (w)
$=2$
c. Maksimum iterasi (MaxIter)
$=100$
d. Error terkecil yang diharapkan $(\xi) \quad=10^{-3}$
e. Fungsi objektif awal $\left(\mathrm{P}_{0}\right)$
$=0$

Langkah pertama adalah memulai perhitungan dengan terlebih dahulu bangkitkan bilangan random sebagai matriks partisi awal.

Matriks partisi awal U yang terbentuk (secara random) adalah sebagai berikut:

$$
U=\left[\begin{array}{lll}
0.0239 & 0.9445 & 0.0316 \\
0.2307 & 0.1330 & 0.6362 \\
0.1578 & 0.1088 & 0.7334 \\
0.1684 & 0.2020 & 0.6296 \\
0.3704 & 0.1568 & 0.4728 \\
0.9467 & 0.0226 & 0.0306 \\
0.8924 & 0.0397 & 0.0678 \\
0.0684 & 0.0532 & 0.8784 \\
0.0449 & 0.9171 & 0.0381 \\
0.2556 & 0.2290 & 0.5154 \\
0.2328 & 0.0625 & 0.7046
\end{array}\right]
$$

Langkah kedua adalah menentukan pusat cluster $V_{k j}$ dengan $k=1,2,3$; dan $j=1,2,3,4,5$ pada setiap iterasi, pada iterasi ke-1, diperoleh pusat cluster sebagai berikut :

$$
V_{k j}=\left[\begin{array}{ccccc}
109,819.03 & 53.60 & 45,835,80 & 68,686.97 & 6.88 \\
72,751.21 & 48.95 & 32,891.73 & 47,614.52 & 4.76 \\
123,771.69 & 48.72 & 49,698.45 & 78,415.76 & 6.10
\end{array}\right]
$$

Langkah ketiga adalah menghitung fungsi objektif. Perhitungan fungsi Objektifnya pada iterasai ke-1, selengkapnya dapat dilihat pada lampiran 2 dan di peroleh $P_{1}=62,725,531,584.6956$

Langkah keempat yaitu, hitung perubahan matriks partisi. Perbaikan Matriks partisi U selengkapnya disajikan dalam lampiran 2. Perhitungan derajat keanggotaan baru yang terhimpun dalam matriks partisi seperti terlihat pada tabel pada lampiran 2. Pengalian setiap kolom pada tabel dengan $10^{-9}$ hanya ditujukan untuk memperkecil nilai, karena hasil L1, L2, L3, L4, dan L5 yang sangat besar.

Diperoleh Matriks Partisi U atau derajat keanggotaan yang baru sebagai berikut: 


$$
U=\left[\begin{array}{lll}
0.3526 & 0.5121 & 0.1353 \\
0.0401 & 0.9412 & 0.0187 \\
0.3481 & 0.2446 & 0.4072 \\
0.4922 & 0.3572 & 0.1506 \\
0.0208 & 0.9676 & 0.0116 \\
0.1421 & 0.0197 & 0.8382 \\
0.0592 & 0.9134 & 0.0274 \\
0.1192 & 0.8038 & 0.0769 \\
0.1766 & 0.7002 & 0.1232 \\
0.3483 & 0.2416 & 0.4101 \\
0.1502 & 0.7484 & 0.1014
\end{array}\right]
$$

Langkah kelima cek kondisi berhenti.

Karena $\left|P_{1}-P_{0}\right|=|62,725,531,584.6956-0|=62,725,531,584.6956 \gg \xi=10^{-3}$ maka harus dilanjutkan keiterasi ke-2.

Pada iterasi ke-2, langkah pertama yaitu memulai perhitungan dengan terlebih dahulu menjadikan perubahan matriks pada iterasi ke-2 sebagai matriks partisi awal.

Langkah kedua, dengan menggunakan matrik spartisi U yang baru, dihitung kembali 3 pusat cluster $V_{k j}$ dengan $k=1,2,3$; dan $j=1,2,3,4,5$ sebagai berikut:

$$
V_{k j}=\left[\begin{array}{ccccc}
153,846.00 & 51.27 & 65,418.47 & 103,624.47 & 7.07 \\
72,864.66 & 50.30 & 30,172.69 & 44,926.18 & 5.11 \\
174,653.82 & 52.46 & 72,044.80 & 109,584.72 & 7.84
\end{array}\right]
$$

Langkah ketiga yaitu menghitung fungsi objektif. Perhitungan fungsi Objektifnya padai terasai ke-2, selengkapnya dapat dilihat pada lampiran 3 dan di peroleh $P_{2}=32,127,750,076.9494$

Langkah keempat yaitu, hitung perubahan matriks partisi. Perbaikan Matriks Partisi U selengkapnya disajikan dalam lampiran 3.Perhitungan derajat keanggotaan baru yang terhimpun dalam matriks partisi dapat dilihat pada lampiran 3. Pengalian setiap kolom pada tabel dengan $10^{-9}$ hanya ditujukan untuk memperkecil nilai, karena hasil L1, L2, L3, L4, dan L5 yang sangat besar. Diperoleh Matriks Partisi U atau derajat keanggotaan yang baru sebagai berikut:

$$
U=\left[\begin{array}{lll}
0.0810 & 0.8682 & 0.0507 \\
0.0102 & 0.9830 & 0.0068 \\
0.3712 & 0.1419 & 0.4869 \\
0.1003 & 0.8382 & 0.0615 \\
0.0019 & 0.9968 & 0.0013 \\
0.6117 & 0.1430 & 0.2453 \\
0.0141 & 0.9766 & 0.0093 \\
0.0330 & 0.9427 & 0.0243 \\
0.0692 & 0.8781 & 0.0528 \\
0.3716 & 0.1355 & 0.4929 \\
0.0514 & 0.9100 & 0.0386
\end{array}\right]
$$

Langkah kelima yaitu cek kondisi berhenti, karena $\left|P_{2}-P_{1}\right|=|32,127,750,076.9494-62,725,531,584.6956|=29,597,781,507.7461 \gg \xi=$ $10^{-3}$ maka harus dilanjutkan ke iterasi ke-3.

Demikian seterusnya hingga $\left|P_{t}-P_{t-1}\right|<\xi=10^{-3}$. Untuk kasus ini, proses baru akan berhenti setelah iterasi ke-42. Pada iterasi ke -42, dihitung kembali 3 pusat cluster $V_{k j}$ dengan $k=1,2,3$; dan $j=1,2,3,4,5$ sebagai berikut:

$$
V_{k j}=\left[\begin{array}{ccccc}
90,557.34 & 54.69 & 41,918.48 & 60,366.56 & 5.72 \\
53,639.21 & 44.76 & 19,145.52 & 28,458.06 & 4.68 \\
286,526.92 & 48.07 & 114,132.36 & 191,123.48 & 10.45
\end{array}\right]
$$

Informasi yang dapat diperoleh dari ketiga pusat cluster diatas adalah: 
Pada Provinsi Maluku, Tingkat pengangguran dapat dikelompokkan menjadi 3 kelompok:

1. Kelompok pertama (Pengangguran tingkat rendah), berisi kabupaten-kabupaten yang memiliki jumlah penduduk sekitar 90,557.34 jiwa; memiliki tingkat partisipasi angkatan kerja sekitar 54.69\%; memiliki Jumlah angkatan kerja sekitar 41,918.48 orang; memiliki jumalah penduduk yang berusia $>15$ tahun sekitar 60,366.56 orang; dan memiliki tingkat pengangguran terbuka sekitar 5.72\%.

2. Kelompok kedua (Pengangguran tingkat sedang), berisi kabupaten-kabupaten yang memiliki jumlah penduduk sekitar 53,639.21 jiwa; memiliki tingkat partisipasi angkatan kerja sekitar 44.76\%; memiliki Jumlah angkatan kerja sekitar 19,145.52 orang; memiliki jumalah penduduk yang berusia> 15 tahun sekitar 28,458.06 orang; dan memiliki tingkat pengangguran terbuka sekitar 4.68\%.

3. Kelompok ketiga (Pengangguran tingkat tinggi), berisi kabupaten-kabupaten yang memiliki jumlah penduduk sekitar 286,526.92 jiwa; memiliki tingkat partisipasi angkatan kerja sekitar 48.07\%; memiliki Jumlah angkatan kerja sekitar 114,132.36 orang; memiliki jumalah penduduk yang berusia $>15$ tahun sekitar 191,123.48 orang; dan memiliki tingkat pengangguran terbuka sekitar 10.45\%.

Beberapa hal penting yang diperoleh dalam proses pengklasteran ini adalah nilai fungsi obyektif selama iterasi, pusat cluster serta derajat keanggotaan setiap cluster pada iterasi terakhir.

Proses perhitungan fungsi objektif dapat dilihat pada lampiran 2 sampai lampiran 43, berikut ini hanya tabel nilai fungsi objektif dari 42 iterasi:

Tabel 1. Nilai Fungsi Objektif dari 42 Iterasi

\begin{tabular}{|c|c|}
\hline Iterasi ke- & Nilai Fungsi Objektif \\
\hline 1 & $62,725,531,584.6956$ \\
\hline 2 & $32,127,750,076.9494$ \\
\hline 3 & $10,686,839,517.7767$ \\
\hline 4 & $6,518,573,826.3522$ \\
\hline 5 & $4,180,644,477.1363$ \\
\hline 6 & $4,000,149,126.8185$ \\
\hline 7 & $3,885,562,448.4606$ \\
\hline 8 & $3,772,024,525.4177$ \\
\hline 9 & $3,634,874,744.0891$ \\
\hline 10 & $3,466,377,907.6328$ \\
\hline$\vdots$ & \\
\hline 40 & $2,949,480,028.3424$ \\
\hline 41 & $2,949,480,028.3422$ \\
\hline 42 & $2,949,480,028.3422$ \\
\hline
\end{tabular}

Pada iterasi ke- 42, diperoleh Matriks Partisi U atau derajat keanggotaan yang baru sebagai berikut:

Tabel 2. Derajat Keanggotaan pada Iterasi ke- 42

\begin{tabular}{|c|c|c|}
\hline $\boldsymbol{\mu}_{\boldsymbol{i} \mathbf{1}}$ & $\boldsymbol{\mu}_{\boldsymbol{i} \mathbf{2}}$ & $\boldsymbol{\mu}_{\boldsymbol{i} \mathbf{3}}$ \\
\hline 0.9768 & 0.0222 & 0.0010 \\
\hline 0.8175 & 0.1790 & 0.0035 \\
\hline 0.0008 & 0.0006 & 0.9986 \\
\hline 0.9982 & 0.0017 & 0.0001 \\
\hline 0.3530 & 0.6426 & 0.0044 \\
\hline 0.7807 & 0.1756 & 0.0437 \\
\hline 0.8483 & 0.1485 & 0.0032 \\
\hline 0.0053 & 0.9946 & 0.0002 \\
\hline 0.0395 & 0.9587 & 0.0018 \\
\hline 0.0008 & 0.0006 & 0.9986 \\
\hline 0.0096 & 0.9900 & 0.0004 \\
\hline
\end{tabular}


Dari derajat keanggotaan pada iterasi terakhir tersebut dapat diperoleh informasi mengenai kecenderungan untuk setiap observasi masuk ke cluster mana. Derajat keanggotaan terbesar menunjukkan bahwa kecenderungan tertinggi observasi untuk masuk mejadi anggota cluster tertentu. Kecenderungan cluster secara keseluruhan dapat dilihat dalam tabel 3:

Tabel 3. Kecenderungan Cluster

\begin{tabular}{|l|c|c|c|c|c|c|}
\hline \multirow{2}{*}{\multicolumn{1}{|c|}{ Nama Kabupaten }} & \multicolumn{3}{c|}{$\begin{array}{c}\text { Derajat keanggotaan pada } \\
\text { cluster ke- }\end{array}$} & \multicolumn{3}{c|}{$\begin{array}{c}\text { Data cenderung masuk } \\
\text { cluster ke- }\end{array}$} \\
\cline { 2 - 7 } & $\mathbf{1}$ & $\mathbf{2}$ & $\mathbf{3}$ & $\mathbf{1}$ & $\mathbf{2}$ & $\mathbf{3}$ \\
\hline Maluku Tenggara Barat & 0.9768 & 0.0222 & 0.0010 & $*$ & & \\
\hline Maluku Tenggara & 0.8175 & 0.1790 & 0.0035 & $*$ & & \\
\hline Maluku Tengah & 0.0008 & 0.0006 & 0.9986 & & & $*$ \\
\hline Buru & 0.9982 & 0.0017 & 0.0001 & $*$ & & \\
\hline Kepulauan Aru & 0.3530 & 0.6426 & 0.0044 & & $*$ & \\
\hline Seram Bagian Barat & 0.7807 & 0.1756 & 0.0437 & $*$ & & \\
\hline Seram Bagian Timur & 0.8483 & 0.1485 & 0.0032 & $*$ & & \\
\hline Maluku Barat Daya & 0.0053 & 0.9946 & 0.0002 & & $*$ & \\
\hline Buru Selatan & 0.0395 & 0.9587 & 0.0018 & & $*$ & \\
\hline Ambon & 0.0008 & 0.0006 & 0.9986 & & & $*$ \\
\hline Tual & 0.0096 & 0.9900 & 0.0004 & & $*$ & \\
\hline
\end{tabular}

Informasi yang dapat diperoleh dari tabel kecendurungan cluster di atas adalah :

1. Kelompok pertama (Pengangguran tingkat rendah) yaitu kabupaten Maluku Tenggara Barat, Kabupaten Maluku Tenggara, Kabupaten Kepulauan Buru, Kabupaten Seram Bagian Barat, Kabupaten Seram Bagian Timur

2. Kelompok kedua (pengangguran tingkat sedang) yaitu kabupaten kepulauan Aru, Kabupaten Maluku Barat Daya, Kabupaten Buru Selatan, Kabupaten Kota Tual

3. Kelompok ketiga (pengangguran tingkat tinggi) yaitu Kabupaten Maluku Tengah dan Kabupaten Kota Ambon

\section{Kesimpulan}

Kesimpulan yang diperoleh dari penelitian ini berdasarkan pengelompokan cluster dengan (Kota, Derajat Keanggotaan) adalah Cluster I : (MTB ; 0,9768), (MTr ; 0,8175), (B ; 0,9982), (SBB ; 0,7808), (SBT ; 0,8483), Cluster II : (KA ; 0,6426), (MBD ; 0,9946), (BS ; 0,9587), (T ; 0,9900) dan Cluster III : (MTh ; 0,9986), (A ; 0,9986). Cluster I merupakan kabupaten-kabupaten yang termasuk dalam pengangguran tingkat rendah, Cluster II merupakan kabupaten-kabupaten yang termasuk dalam pengangguran tingkat sedang, dan cluster III kabupaten-kabupaten yang termasuk dalam pengangguran tingkat tinggi.

\section{Daftar Pustaka}

[1] D. S. Kusuma, H. Purnomo, Aplikasi Logika Fuzzy Untuk Pendukung Keputusan., Graha Ilmu, Yogyakarta, 2010.

[2] E. Turban, R. Sharda, and D. Delen, Prentice - hall decision Support and Bussines Intelligence System. $8^{\text {th }}$,Prentice - Hall International Inc, New Jersey, 2007.

[3] E. Sediyono, I. R. Widiasari, \& Milasari, Penentuan Lokasi Fasilitas Gudang menggunakan Fuzzy C - Means (FCM), Jurnal Informatika, Vol.2, No. 2, Desember 2006:155 - 166, 2006.

[4] Mirza, M. Faisal, Metode Clustering dengan Algoritma Fuzzy C-Means untuk Rekomendasi Pemilihan Bidang Keahlian Pada Program Studi Teknik Informatika. Fakultas Ilmu Komputer, Universitas Dian Nuswantoro, Semarang, 2013.

[5] Rerenie's Blog, [2013]. Pengangguran, Inflasi Dan Kebiajakan Pemerintah. (online) (https://www.rerenie.wordpress.com/pengangguran-inflasi-dan-kebijakan-pemerintah) diakses tanggal 17 Mei pukul 19.00 WIT.

[6] U. Fadilah, Analisis Penyandang Masalah Kesejahteraan Sosial di Indonesia Menggunakan Metode Fuzzy CMeans Clustering dan Biplot. Fakultas Sains dan Teknologi, Universitas Islam Negri Syarif Hidayatullah, Jakarta, 2011.

[7] Ulfah, A. Noviciatie, Analisis Kinerja algoritma Fuzzy C-Means pada data Kemiskinan. Jatisi. Yogyakarta, 2015. 